\title{
Genetic Variability for Antioxidant Activity and Total Phenolic Content in Four Major Pulse crops
}

\author{
Jagdish Singh ${ }^{1 *}$, Rajani Kanaujia ${ }^{1}$, Jitendra Kumar ${ }^{2}$, Farindra Singh ${ }^{2}$, Srivastava AK ${ }^{2}$ and NP Singh ${ }^{3}$ \\ ${ }^{1}$ Division of Basic Science, ICAR-Indian Institute of Pulses Research, India \\ ${ }^{2}$ Division of Crop Improvement, ICAR-Indian Institute of Pulses Research, India \\ ${ }^{3}$ Director, ICAR-Indian Institute of Pulses Research, India
}

*Corresponding author: Jagdish Singh, Division of Basic Science, ICAR Indian Institute of Pulses Research, Kanpur-208024, UP, India

Submission: December 21, 2017; Published: February 28, 2018

\begin{abstract}
Total phenolic content and antioxidant activity were evaluated in 139 diverse genotypes of four pulse crops including 54 genotypes of chickpea (Cicer arietinum), 37 lentil (Lens culinaris), 21 pigeonpea (Cajanus cajan), and 26 blackgram (Vigna mungo). Results indicate significant genotypic variation ( $\mathrm{p}<0.01$ ) for total phenolic content (TPC) as well as antioxidant activity (AOA). Amongst the four major pulse crops tested, maximum mean phenolic content was recorded in blackgram genotypes (7.01mg GAE/g), followed by lentil (3.46mg GAE/g), pigeonpea (3.32mg GAE/g) and chickpea (2.30 mg GAE/g). In general, the Mediterranean landraces of lentil had higher phenolic content as compared to the other lentil varieties and breeding lines. Amongst the chickpea genotypes the phenolic content ranged from 0.40 to $5.63 \mathrm{mg} \mathrm{GAE} / \mathrm{g}$ and comparatively higher value for phenolic content was recorded in desi types (2.67mg GAE/g) as compared to the Kabuli types (1.05mg GAE/g).

The antioxidant activity (AOA) was assayed in mature dry seeds utilizing DPPH (2,2-Diphenyl-1-picryl hydrazyl) radical scavenging assay which ranged from 1.73 to $19.14 \mu \mathrm{mole}$ Trolox/g tissue. As observed for TPC, highest AOA was also recorded in blackgram genotypes $(19.14 \mu \mathrm{mole}$ Trolox/g tissue), followed by pigeonpea $(2.72 \mu$ mole Trolox/g tissue), chickpea $(2.05 \mu$ mole Trolox/g tissue) and lentil $(1.73 \mu$ mole Trolox/g tissue). Highly significant genotypic as well as phenotypic correlation $(\mathrm{p}<0.01)$ was recorded between phenolic content and antioxidant activity in chickpea, lentil as well as blackgram ( $\mathrm{rG}$ values ranging from 0.268 to 0.850 and $\mathrm{rP}$ from 0.253 to 0.817 ), however, surprisingly the values were non-significant in case of pigeonpea. Strongest genotypic correlation was recorded in chickpea $(\mathrm{rG}=0.850)$, followed by lentil $(\mathrm{rG}=0.744)$, and blackgram ( $\mathrm{rG}=0.268)$. High broad-sense heritability (h2bs) ( 0.89 to 0.97 ) for phenol content was recorded which indicates that substantial portion of total variation for phenolic content is due to genetic effects.
\end{abstract}

Keywords: 2,2'-diphenyl-1-picryl hydrazyl (DPPH); Polyphenol content; Antioxidant activity, Black gram; Lentil; Pigeon pea; Chickpea

\section{Introduction}

Pulses in general are nutritionally enriched as they have high protein content, as compared to staple cereals. They are produced on around $12-15 \%$ of the global arable land and their contribution to total human dietary protein requirement is approximately $30 \%$ [1]. The pulse seeds are utilized as a high protein source not only because of their nutritional value, but also as functional foods [2] and for their adaptability to marginal soils and climates. The potential health benefits of pulses is attributed to the presence of secondary metabolites such as phenolic compounds (e.g. phenolic acids, flavonoids, quinones, lignans, stilbenes, tannins) that possess antioxidant properties [3]. These plant phenolics retard the oxidative degradation of lipids, DNA and protein [4]. The excessive free radical production and lipid peroxidation is the main cause of the pathogenesis of several degenerative diseases [5]. Antioxidants act as protective factors against the oxidative damage [6] and prevent the development of chronic diseases such as cancer, heart disease, stroke, and cataracts [7].
Phenolic compounds swic, anti-artherogenic, antiinflammatory, anti-microbial, antioxidant, cardio protective, and vaso-dilatory effects $[8,9]$ and play an important role in the body's defence system against Reactive Oxygen Species (ROS) [10]. The anti-oxidant activity of phenolics is mainly because of their redox properties. Which could be a major determinant of antioxidant potential of foods [11]. Epidemiological studies have also shown that consumption of food rich in phenolics can slow the progression of various degenerative diseases [12]. Therefore, the current focus is on the anti-oxidant action of phenolics. Although the intake of natural antioxidants has been associated with reduced risks of such degenerative diseases but still there is considerable controversy in this area [13]. Some phenolic compounds can also reduce protein digestibility [14] and mineral bioavailability [15]. Exploitation of genetic variation is the basis for crop improvement through plant breeding [16]. However, information on genetic variability on phenol content and antioxidant activity of major pulse crops is 
scanty. Thus, this work was initiated to assess the genetic variability for total phenol content and antioxidant activity in mature seeds of 53 chickpea, 30 lentil, 22 pigeonpea and 26 blackgram genotypes.

\section{Materials and Methods}

\section{Chemicals and reagents}

2,2'-diphenyl-1-picryl hydrazyl (DPPH), Trolox (6-hydroxy2,5,7,8-tetramethylchromane-2-carboxylic acid) and bovine serum albumin (BSA) were purchased from Sigma/Aldrich (St. Louis, MO), and Folin-Ciocalteu phenol reagent, gallic acid, were obtained from SRL, India All other reagents and chemicals used were of analytical grade procured from local sources. MilliQ water was used in the study.

\section{Sample collection and extraction}

Seed samples of 54 chickpea (Cicer arietinum), 37 lentil (Lens culinaris), 21 pigeonpea (Cajanus cajan) and 26 black gram (Phaseolus mungo) genotypes were obtained from Crop Improvement Division of this institute. The collected samples were ground to fine powder by a Kenwood Multi-Mill (Kenwood Ltd., UK) and passed through a sieve (24 mesh). The ground samples were dried to constant weight in desiccant at room temperature $(\sim 23$ ${ }^{\circ} \mathrm{C}$ ). $100 \mathrm{mg}$ powdered sample was extracted with $100 \mathrm{~mL}$ of $80 \%$ methanol: water $(80: 20, \mathrm{v} / \mathrm{v})$ at $35^{\circ} \mathrm{C}$ for $24 \mathrm{hr}$ in a Shaking Water Bath. Then the extracts were centrifuged at $10000 \times \mathrm{g}$ for $15 \mathrm{~min}$ and the supernatants were removed into new tubes. Extracts were kept in dark at $4{ }^{\circ} \mathrm{C}$ until used for determination of total phenolic content (TPC).

\section{Estimation of DPPH Radical Scavenging Activity}

The DPPH radical scavenging activity was estimated spectrophotometrically according to the method (17). Briefly, $100 \mu \mathrm{l}$ Results and Discussion of sample extract was added to $2.9 \mathrm{ml}$ of DPPH reagent $(0.1 \mathrm{mM}$ in methanol) and vortexed vigorously. It was incubated in dark for $30 \mathrm{~min}$ at room temperature and the discolouration of DPPH was measured against blank at $517 \mathrm{~nm}$. Trolox standard solution (final concentration $15 \mu \mathrm{M}$ ) in $80 \%$ ethanol was prepared and assayed under same conditions. The absorbance of the resulting oxidized solution was compared to that of the calibrated Trolox standard. Results were expressed in terms of Trolox equivalent antioxidant capacity (TEAC, $\mu$ mol Trolox equivalents per g dry weight of sample).

\section{Estimation of Total Phenolic Content}

Total phenolic content was estimated using the Folin-Ciocalteu's phenol reagent as described previously (18). Briefly, the appropriate dilutions of the filtered extracts were oxidized with $0.2 \mathrm{~N}$ FolinCiocalteu's phenol reagent and then the reaction was neutralized with saturated sodium carbonate $(75 \mathrm{~g} / \mathrm{L})$. The intensity of the blue-colored complex was measured at 760nm using a Shimadzu UV-Vis spectrophotometer (after incubation for $2 \mathrm{hr}$ at $23^{\circ} \mathrm{C}$ ). Gallic acid was used as the standard and results expressed asmg of gallic acid equivalents per g dry weight (mg GAE/g).

\section{Statistical Analysis}

Analyses were performed in triplicate. The data were analysed by analysis of variance (ANOVA) [19] to detect significant differences between genotypes, while Pearson correlation coefficients were calculated by SPSS software (SPSS Inc., Chicago, IL, USA) at a probability level of $(\mathrm{p} \leq 0.05)$. Mean values were calculated and compared using t-test at 5\% level of significance. Genetic parameters (variance components, genotypic and phenotypic coefficients of variations, heritability, genetic advance, correlations and path coefficients) were estimated [20].

Table 1: ANOVA for quality traits in 26 lines of Blackgram and 21 lines of Pigeonpea.

\begin{tabular}{|c|c|c|c|c|c|c|}
\hline \multirow{2}{*}{ Source } & \multicolumn{5}{|c|}{ Mean sum of square due to } \\
\cline { 2 - 7 } & \multicolumn{2}{|c|}{ Blackgram } & AOA & df & PC & AOA \\
\cline { 2 - 7 } & $\mathrm{df}$ & PC & 0.91 & 2 & 0.35 & $4.20^{* *}$ \\
\hline Replications & 2 & $1.38^{* *}$ & $73.37^{* *}$ & 20 & $10.62^{* *}$ & $2.63^{* *}$ \\
\hline Genotype & 25 & $3.22^{* *}$ & $493.63^{* *}$ & 1 & 0.42 & $23.99^{* *}$ \\
\hline Year & 1 & $197.66^{* *}$ & $72.02^{* *}$ & 20 & $0.53^{* *}$ & $1.23^{* *}$ \\
\hline Genotype x Year & 25 & $4.95^{* *}$ & 0.61 & 82 & 0.2 & 0.2 \\
\hline Error & 102 & 0.1 & & & & 0.2 \\
\hline
\end{tabular}

** Significant at $\mathrm{P}=0.01$.

Table 2: ANOVA for quality traits in 37 lines of Lentil and 54 lines of Chickpea.

\begin{tabular}{|c|c|c|c|c|c|c|}
\hline \multirow{2}{*}{ Source } & \multicolumn{9}{|c|}{ Mean sum of square due to } \\
\cline { 2 - 8 } & \multicolumn{3}{|c|}{ Lentil } & df & PC & AOA \\
\cline { 2 - 8 } & $\mathrm{df}$ & PC & AOA & 2 & 0.19 & $0.71^{* *}$ \\
\hline Replications & 2 & 0.01 & $0.09^{* *}$ & 53 & $3.08^{* *}$ & $1.86^{* *}$ \\
\hline Genotype & 36 & $3.93^{* *}$ & $0.62^{* *}$ & 106 & 0.08 & 0.04 \\
\hline Error & 72 & 0.095 & 0.001 & & \\
\hline
\end{tabular}

** Significant at $\mathrm{P}=0.01$. 
Significant genotypic variation was recorded for total phenolic content (TPC) as well as antioxidant activity (AOA) among the 139diverse genotypes of four pulse crops including 54 genotypes of chickpea, 37 lentil, 21 pigeon pea, and 26 black gram (Table 1 \& 2). Amongst the four major pulse crops tested, maximum mean phenolic content was recorded in black gram genotypes $(7.01 \mathrm{mg}$ $\mathrm{GAE} / \mathrm{g}$ ) followed by lentil (3.46mg GAE/g), pigeon pea (3.32mg GAE/g) and chickpea (2.30mg GAE/g) (Table 3). Amongst the 26 black gram genotypes the phenol content ranged from 5.90 to $9.03 \mathrm{mg} \mathrm{GAE} / \mathrm{g}$ and maximum mean TPC $(9.03 \mathrm{mg} \mathrm{GAE} / \mathrm{g})$ was recorded in genotype PU-31 followed by IPU-99-200 (8.35mg GAE/g) and PDU-1 (8.17mg GAE/g). In 37 genotypes of lentil, TPC ranged from 1.20 to $6.10 \mathrm{mg} \mathrm{GAE} / \mathrm{g}$ and the maximum value for TPC content was recorded in Mediterranean landrace IG 112128 (6.10mg GAE/g). In general, the Mediterranean landraces of lentil had higher phenol content as compared to the other released varieties and breeding lines. In pigeon pea genotypes the total phenol content ranged from 0.83 to $5.80 \mathrm{mg} \mathrm{GAE} / \mathrm{g}$ and maximum mean phenol content was recorded in $\mathrm{cv}$.

Table 3: Estimates of genotypic $(\mathrm{rG})$ and phenotypic $(\mathrm{rP})$ correlation coefficient for polyphenols and AOA content in pulse crops.

\begin{tabular}{|l|c|c|c|c|c|}
\hline \multirow{2}{*}{ Characters } & & \multicolumn{4}{|c|}{ AOA } \\
\cline { 3 - 6 } & & Chickpea & Lentil & Blackgram & Pigeonpea \\
\hline \multirow{2}{*}{ Polyphenols } & rG & $0.850^{* *}$ & $0.744^{* *}$ & $0.268^{*}$ & 0.203 \\
\cline { 2 - 6 } & rP & $0.817^{* *}$ & $0.715^{* *}$ & $0.253^{*}$ & 0.174 \\
\hline
\end{tabular}

** Significant at $\mathrm{P}=0.01$,

* Significant at $\mathrm{P}=0.05$, rG: Genotypic correlation, rP: Phenotypic correlation

Birsa Arahar (5.52mg GAE/g), followed by LRG-38 (5.28mg GAE/g). Amongst the 54 chickpea genotypes the phenol content ranged from 0.40 to $5.63 \mathrm{mg} \mathrm{GAE} / \mathrm{g}$ and comparatively higher value for phenol content was recorded in desi types $(2.67 \mathrm{mg} \mathrm{GAE} / \mathrm{g}$ ) as compared to the Kabuli types (1.05mg GAE/g). In the 36 desi types the phenol content ranged from $1.60-3.32 \mathrm{mg} \mathrm{GAE} / \mathrm{g}$ and $0.51-1.36 \mathrm{mg}$ GAE/g in the 14 kabuli types, whereas, in 03 wild accessions the phenol content was significantly high which ranged from 4.48 to $5.65 \mathrm{mg}$ GAE/g (Table 3).

The TPC in chickpea as recorded in the present study is close to recently published reports $[21,22]$, where the total phenolic content in chickpea was reported to range from 0.92 to $1.68 \mathrm{mg}$ gallic acid equivalents/ g. In another study [23], the phenolic content was reported as $12 \mathrm{mg} / \mathrm{g}$ for lentil, $2.2 \mathrm{mg} / \mathrm{g}$ for chickpea, $2.5 \mathrm{mg} / \mathrm{g}$ for yellow peas and $1.2 \mathrm{mg} / \mathrm{g}$ for green peas The values reported for chickpea $(2.2 \mathrm{mg} / \mathrm{g})$ in this study is very close to the mean values of phenol content reported in our study, whereas, value for phenol content in lentil $(12 \mathrm{mg} / \mathrm{g})$ is higher than the values reported in our study. In another study [24], the phenolic content was estimated for germinated and cooked pulses and reported that the TPC in non-germinated seeds varied from $1.54-6.71 \mathrm{mg} / \mathrm{g}$ in different pulses, with red gram (pigeon pea) showing the highest total phenolic content (6.71mg ferulic acid/g flour). The values for TPC reported in other pulses was, black gram $(5.70 \mathrm{mg} / \mathrm{g})$, green gram (mungbean) $(3.05 \mathrm{mg} / \mathrm{g})$ and lentil $(6.20 \mathrm{mg} / \mathrm{g})$. It has also been reported (25) that black gram dhal had the highest $(418 \mathrm{mg} / 100$ g) whereas, green gram dhal showed the least TPC $(62.4 \mathrm{mg} / 100 \mathrm{~g})$ amongst the tested pulses. The total phenol content of pulses was analyzed and it was reported that the total phenols ranged from 54.43mg GAE/100g to 345.2mg GAE/100g [26].

Rajmash had the highest total phenolic content $(345.2 \pm 4.8 \mathrm{mg}$ $\mathrm{GAE} / 100 \mathrm{~g}$ ) followed by green gram (mung bean whole) (193.59 $\pm 6.3 \mathrm{mg} \mathrm{GAE} / 100 \mathrm{~g}$ ) and Bengal gram (chickpea whole, black) (114.33 $\pm 5.9 \mathrm{mg} \mathrm{GAE} / 100 \mathrm{~g})$ while bengal gram (chickpea) dhal $(96.25 \pm 2.8 \mathrm{mg}$ GAE/100g), red gram dhal (pigeonpea) $(73.49 \pm 2.2 \mathrm{mg} \mathrm{GAE} / 100 \mathrm{~g})$ and green gram dhal (mung bean) $(54.43 \pm 4.2 \mathrm{mg} \mathrm{GAE} / 100 \mathrm{~g})$ had lesser total phenolic content. In pigeonpea, it has been reported that the whole seed extract had higher total phenol content $(9.44 \pm 0.02 \mathrm{mg}$ GAE/g extract) as compared to the cotyledons [27].

The antioxidant activity (AOA) was assayed in mature dry seeds utilizing DPPH (2,2-Diphenyl-1-picryl hydrazyl) radical scavenging assay which ranged from 1.73 to $19.14 \mu$ mole Trolox/g tissue (Table 3). As observed for TPC, highest AOA was also recorded in black gram genotypes (19.14 $\mu$ mole Trolox/g tissue) followed by pigeon pea $(2.72 \mu$ mole Trolox/g tissue), chickpea $(2.05 \mu$ mole Trolox/g tissue) and lentil (1.73 $\mu$ mole Trolox/g tissue) (Table 3). Significant genotypic differences were recorded in AOA for all the four pulse crops. In the black gram genotypes the AOA ranged from 12.90 to $26.00 \mu$ mole Trolox/g tissue and maximum mean AOA was recorded in black gram genotype UH-85-3 $(26.00 \mu$ mole Trolox/g tissue $)$

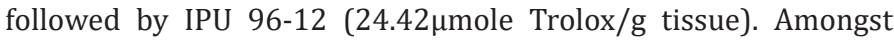
the pigeon pea genotypes the AOA ranged from 0.77 to $3.78 \mu$ mole Trolox/g tissue and maximum AOA was recorded in pigeon pea genotype IPA-15F ( $3.67 \mu$ mole Trolox/g tissue) followed by IPA

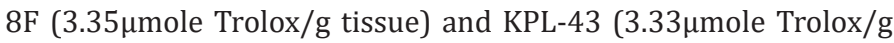
tissue). Amongst the lentil cultivars, the AOA ranged from 1.23 to $2.56 \mu$ mole Trolox/g tissue and maximum AOA was recorded in


Mediterranean landraces (2.33 to $2.43 \mu$ mole Trolox/g tissue).

Surprisingly, only one of the five Mediterranean landraces tested, showed low AOA (1.33 Mediterranean landraces) as well as low TPC (3.43mg GAE/g). In the chickpea genotypes, the AOA ranged from 1.01-3.09 $\mu \mathrm{M}$ Trolox equivalents/g in the desi types and $0.41-1.16 \mu \mathrm{M}$ Trolox equivalents/g in the Kabuli types. In the 3 wild accessions of chickpea the antioxidant activity ranged from 2.25 to $2.89 \mu \mathrm{M}$ Trolox equivalents/g. The desi type chickpea genotypes as well as the wild accessions with colored testa (seed coat) contained high levels of polyphenolic compounds and also exhibited high levels of antioxidant activity.

In an earlier study, high correlation between phenolic composition and antioxidant activity of legume extract was reported [2]. The antioxidant activity of lentils, chickpea and pea was investigated and it was reported that total antioxidant activity (AA) determined by ABTS (2,2'-azinobis-3-ethyl-benzthiazoline-6sulfonic acid) assay was highest in lentil $(14 \mu \mathrm{mol}$ Trolox equivalent 
antioxidant capacity (TEAC) /g) and lowest in green peas $(1.9 \mu \mathrm{mol}$ TEAC /g) [23]. They also reported that total AA was significantly correlated with total phenol content. The total antioxidant capacity (TAC) for chickpea was reported as $10.7 \pm 1.3 \mathrm{mmol}$ Trolox $/ \mathrm{kg}$ and lentil $34.9 \pm 2.4$ to $38.2 \pm 2.3 \mathrm{mmol}$ Trolox $/ \mathrm{kg}$ [28]. In a recent study [29], the total poly-phenols, flavonoids and antioxidant capacity in colored chickpea lines was estimated and reported that both TPC and TFC varied significantly among different lines and were highly correlated to antioxidant activity.

In the present study, highly significant genotypic as well as Table 4: Genetic components for polyphenols and AOA in pulses. phenotypic correlation $(\mathrm{p}<0.01)$ was recorded between phenol content and antioxidant activity in chickpea, lentil as well as blackgram (Table 3) (rG values ranging from 0.268 to 0.850 and rP from 0.253 to 0.817 ), however, surprisingly the values were non-significant in case of pigeonpea (Table 4). Strongest genotypic correlation was recorded in chickpea $(\mathrm{rG}=0.850)$ followed by lentil $\mathrm{rG}=0.744$ ) and blackgram ( $\mathrm{rG}=0.268)$. These findings clearly suggest that total phenol content may be important contributor to the antioxidant activity in case of chickpea, lentil and blackgram and are in agreement with the earlier reports [30].

\begin{tabular}{|c|c|c|c|c|c|c|}
\hline \multirow{2}{*}{ Crops } & \multirow{2}{*}{ Mean } & \multirow{2}{*}{ Range } & Coefficient of variation & Heritability (Broad Sense) & \multicolumn{2}{|c|}{ Expected genetic advance as $\%$ of mean } \\
\hline & & & Genotypic (GCV) & \multicolumn{3}{|c|}{ Phenotypic (PCV) } \\
\hline \multicolumn{7}{|c|}{ Polyphenols (mg/g) } \\
\hline Chickpea & 2.3 & 0.40 to 5.63 & 43.42 & 45.19 & 0.923 & 85.92 \\
\hline Lentil & 3.46 & 1.20 to 6.10 & 32.7 & 33.89 & 0.931 & 65 \\
\hline Blackgram & 7.01 & 5.90 to 9.00 & 10.19 & 10.74 & 0.899 & 19.9 \\
\hline Pigeonpea & 3.32 & 0.83 to 5.80 & 39.83 & 40.38 & 0.973 & 80.93 \\
\hline \multicolumn{7}{|c|}{$\mathrm{AOA}$} \\
\hline Chickpea & 2.05 & 0.43 to 3.10 & 37.95 & 39.16 & 0.939 & 75.78 \\
\hline Lentil & 1.73 & 1.23 to 2.56 & 26.45 & 26.51 & 0.996 & 54.36 \\
\hline Blackgram & 19.14 & 12.9 to 26.0 & 18.18 & 18.44 & 0.971 & 36.9 \\
\hline Pigeonpea & 2.72 & 0.77 to 3.78 & 24.23 & 27.32 & 0.787 & 44.27 \\
\hline
\end{tabular}

In another study [31], it was shown that the total phenolic content highly correlated with the antioxidant activity in pulses like faba bean, mungbean, soybean and zuaki bean. The chemical and cellular antioxidant activities and phenolic profiles of 11 lentil cultivars was estimated and showed that different phenotype lentils possessed considerable variations in their individual phenolic compounds, as well as chemical and cellular antioxidant activities [32]. They have further reported that caffeic acid, catechin, epicatechin and total flavonoids significantly $(\mathrm{p}<0.05)$ correlated with peroxyl radical scavenging assay. In another study [24], it has been reported that the total phenolic content highly correlated with the antioxidant activity in the pulses. However in contrast to this, several studies have reported that there is no significant correlation between TPC and AOA among plant extracts $[33,34]$. The total antioxidant capacity (TAC) and total phenol content of pulses was estimated and reported that the TAC of pulses ranged from $5246.81 \mu \mathrm{mol} \mathrm{TE} / 100 \mathrm{~g}$ in soyabean to $1879.16 \mu \mathrm{mol}$ $\mathrm{TE} / 100 \mathrm{~g}$ in pigeonpea by ORAC assay and $563.61 \mu \mathrm{mol} \mathrm{TE} / 100 \mathrm{~g}$ in rajmash to $26.97 \mu \mathrm{mol} \mathrm{TE} / 100 \mathrm{~g}$ in chickpea whole (white) by FRAP assay [26]. They have reported that there was no correlation observed between the TAC values by both the methods in both raw $(\mathrm{r}=0.2174)$ and cooked $(\mathrm{r}=-0.0825)$ pulses. In an earlier study [25] also, it has been reported that ferric reducing antioxidant power (FRAP) assay ( $\mathrm{r}=0.91)$ and reducing power $(\mathrm{r}=0.90)$ showed significant correlation with total phenol content (TPC) in cereals and millets, but not in pulses and legumes.

Further, the inheritance of nutritional traits appears to be mostly quantitative, influenced by the environment, but more specific to source genotypes [35]. Thus to determine whether the phenol content in a particular crop can be improved by traditional breeding methods, it must be known to what extent these traits are heritable.

\section{Genetic Components of TPC and AOA}

In general the phenotypic coefficient of variability was higher than corresponding genotypic coefficients of variability among all four pulses for both TPC and AOA content reflecting the influence of environment on these traits. This was expected as there is always some environmental influence on the expression of quantitative traits (Table 4). Higher estimate of phenotypic and genotypic coefficient of variation for both TPC and AOA was observed in chickpea, lentil and pigeon pea indicating presence of exploitable genetic variability for the traits in these pulse crops. However, estimate of phenotypic and genotypic coefficient of variation for both TPC and AOA were relatively lower in black gram reflecting poor exploitable variability for the traits among the genotypes under study.

Heritability and genetic advance as percent of mean provides a clear picture of the scope for improvement in various quality traits through selection. In the present study high broad-sense heritability (h2bs) (0.89 to 0.97) was recorded among all the pulses for TPC. The genetic gain due to selection was higher in all the pulses except black gram genotypes which exhibited poor variability in the present study. Although heritability estimates for grain phenol content are high enough to permit effective selection for these traits in pulse crops the genetic gain estimate was high in 
chickpea and pigeonpea, moderate in lentil and poor in black gram. Similarly, higher genetic advance due to selection was expected in chickpea followed by lentil, pigeon pea and black gram.

\section{Conclusion}

Our findings suggest that there was significant genotypic variation $(p<0.01)$ for total phenolic content (TPC) as well as antioxidant activity (AOA) in 139 diverse genotypes of four pulse crops. Amongst the four major pulse crops tested, maximum mean phenolic content was recorded in blackgram genotypes followed by lentil, pigeon pea and chickpea. In general, the Mediterranean landraces of lentil had higher phenol content as compared to the other lentil varieties and breeding lines. Amongst the chickpea genotypes higher value for phenol content was recorded in desi types as compared to the Kabuli types. Highest antioxidant activity (AOA) was recorded in blackgram genotypes, followed by pigeonpea, chickpea and lentil Highly significant genotypic as well as phenotypic correlation $(\mathrm{p}<0.01)$ was recorded between phenol content and antioxidant activity in chickpea, lentil as well as blackgram, however, surprisingly the values were non-significant in case of pigeonpea. High broad-sense heritability (h2bs) (0.89 to 0.97 ) for phenol content was recorded which indicates that substantial portion of total variation for phenol content is due to genetic effects.

\section{References}

1. Graham PH, Vance CP (2003) Legumes: importance and constraints to greater use. Plant Physiol 131(3): 872-877.

2. Roos de NM (2004) Functional foods: Cardiovascular disease and diabetes. In: Arnoldi A (Ed.), Wood head Publishing Ltd, Cambridge, USA, pp. 1-9.

3. Azevedo A, Gomes JC, Stringheta PC, Gontijo AMC, Padovani CR, et al. (2003) Black bean (Phaseolus vulgaris L) as a protective agent against DNA damage in mice. Food Chem Toxicol 41(12): 1671-1676.

4. Jacob DR, Meyer HE, Solvoll K (2001) Reduced mortality among whole grain bread eaters in men and women in the Norwegian County Study. Eur J Clin Nutr 55(2): 133-147.

5. Pavel S, Borivoj K, Vlastimil K (2006) Determination of total content of phenolic compounds and their antioxidant activity in vegetables evaluation of spectrophotometric methods. J Agric Food Chem 54(3): 607-616.

6. Kikuzaki H, Hisamoto M, Hirose K, Akiyama K, Taniguchi H (2002) Antioxidant properties of ferulic acid and its related compounds. J Agric Food Chem 50(7): 2161-2168

7. Chung KT, Wong TY, Wei CI, Huang YW, Lin Y (1998) Tannins and human health: A review. Crit Rev Food Sci Nutr 38(6): 421-464.

8. Middleton E, Kandaswami C, Theoharides TC (2000) The effects of plant flavonoids on mammalian cells: Implications for inflammation, heart disease and cancer. Pharmacol Rev 52(4): 673-751.

9. Halliwell B (1994) Free radicals, antioxidants, and human disease: curiosity, cause, or consequence? Lancet 344(8924): 721-724.

10. Gutteridge JMC, Halliwell B (2000) Free radicals and antioxidants in the year 2000 - A historical look to the future. Ann N Y Acad Sci 899: 136147.

11. Parr AJ, Bolwell GP (2000) Phenols in plant and in man: The potential for possible nutritional enhancement of the diet by modifying the phenols content or profile. Journal of the Science of Food and Agriculture 80(7): 985-1012.

12. Landbo AK, Meyer AS (2001) Ascorbic acid improves the antioxidant activity of European grape juice to inhibit lipid peroxidation of human LDL in vitro. International Journal of Food Science and Technology 36(7): 727-736.

13. Yang CS, Landau JM, Huang MT, Newmark HL (2001) Inhibition of carcinogenesis by dietary polyphenolic compounds. Annu Rev Nutr 21: 381-406.

14. Chung KT, Wong TY, Wei CI, Huang YW, Lin Y (1998) Tannins and human health: A review. Crit Rev Food Sci Nutr 38(6): 421-464.

15. Sandberg AS (2002) Bioavailability of minerals in legumes. Br J Nutr 88(3): 281-285

16. Ortiz Monasterio I, Palacios Rojas N, Meng E, Pixley K, Trethowan R, et al. (2007) Enhancing the mineral and vitamin content of wheat and maize through plant breeding. Journal of Cereal Science 46(3): 293-307.

17. Brand Williams W, Cuvelier ME, Berset C (1995) Use of a free radical method to evaluate antioxidant activity. LWT- Food Science and Technology 28(1): 25-30.

18. Singleton VL, Rossi JA (1965) Colorimetry of total phenolics with phosphomoly bdicphosphotungstic acid reagents. American Journal of Enology \& Viticulture 16(3): 144-158.

19. Gomez KA, Gomez AA (1984) Statistical procedures for agricultural research. John Wiley \& Sons, New York, USA.

20. Singh RK, Chaudhari BD (1977) Biometrical methods in quantitative genetic analysis. Kalyani Publishers, New Delhi. pp. 3938.

21. Xu BJ, Chang SKC (2007) A comparative study on phenolic profiles and antioxidant activities of legumes as affected by extraction solvents. J Food Sci 72(2): S159-S166.

22. Zia Ul Haq M, Iqbal S, Ahmad S, Bhanger MI, Wiczkowsi W, et al. (2008) Antioxidant potential of desi chickpea varieties commonly consumed in Pakistan. Journal of Food Lipids 15(3): 326-342.

23. Han Hwa, Baik Byung Kee (2008) Antioxidant activity and phenolic content of lentils (Lens culinaris), chickpeas (Cicer arietinum L.), peas (Pisum sativum L) and soybeans (Glycine max), and their quantitative changes during processing. International Journal of Food Science \& Technology 43(11): 1971-1978.

24. Gujral HS, Angurala M, Sharma P, Singh Jaspreet (2011) Phenolic content and antioxidant activity of germinated and cooked pulses. International Journal of Food Properties 14(6): 1366-1374.

25. Sreeramulu D, Reddy CV, Raghunath M (2009) Antioxidant activity of commonly consumed cereals, millets, pulses and legumes in India. Indian J Biochem and Biophys 46(1): 112-115.

26. Karthiga S, Dorothy Jaganathan (2013) Total antioxidant capacity and total phenol content of pulses and root vegetables commonly used in India. International Journal of Food and Nutritional Sciences 2(2): 2429.

27. Savita Rani, Gagan Poswal, Yadav Rajesh, Deen MK (2014) Screening of pigeon pea (Cajanus cajan L.) seeds for study of their flavonoids, total phenolic content and antioxidant properties. International Journal of Pharmaceutical Sciences Review and Research 28(2): 90-94.

28. Açar Özge C, Vural Gökmen, Nicoletta Pellegrini, Vincenzo Fogliano (2009) Direct evaluation of the total antioxidant capacity of raw and roasted pulses, nuts and seeds. European Food Research and Technology 229(6): 961-969.

29. Segev A, Badani H, Kapulnik Y, Shomer IM, Oren Shamir, et al. (2010) Determination of polyphenols, flavonoids, and antioxidant capacity in colored chickpea (cicer arietinum L). J Food Sci 75(2): S115-S119. 
30. Kevers C, Falkowski M, Tabart J, Defraigne J, Dommes J, et al. (2007) Evolution of antioxidant capacity during storage of selected fruits and vegetables. J Agric Food Chem 55: 8596-8603.

31. YuWei L, Wang Q (2015) Effect of processing on phenolic content and antioxidant activity of four commonly consumed pulses in china. Journal of Horticulture 2:130.

32. Baojun, Xu, Chang Sam KC (2010) Phenolic substance characterization and chemical and cell based antioxidant activities of 11 lentils grown in the Northern United States. Journal Agricultural and Food Chemistry 58 (3): 1509-1517.
33. Mariko N, Hassimotto A, Genovese MI, Lajola FM (2005) Antioxidant activity of dietary fruits, vegetables and commercial frozen fruit pulps. J Agric Food Chem 53(8): 2928-2935.

34. Mustafa O, Riesse RN, Tulio AZ, Scheerens JC, Miller AR (2006) Modified 2,2-azino-bis-3-ethylbenzothiazoline-6-sulfonic acid method to measure antioxidant capacity of selected small fruits and comparison to ferric reducing antioxidant power (FRAP) and 2,2'-diphenyl-1-picrylhydrazyl (DPPH) methods. J Agric Food Chem 54(4): 1151-1157.

35. Blair MW, Astudillo C, Grusak M, Graham R, Beebe S (2009) Inheritance of grain iron and zinc content in common bean (Phaseolus vulgaris L.). Molecular Breeding 23: 197-207.

For possible submissions Click Here

\section{Your subsequent submission with Crimson Publishers will attain the below benefits}

- High-level peer review and editorial services

- Freely accessible online immediately upon publication

- Authors retain the copyright to their work

- Licensing it under a Creative Commons license

- Visibility through different online platforms

- Global attainment for your research

- Article availability in different formats (Pdf, E-pub, Full Text)

- Endless customer service

- Reasonable Membership services

- Reprints availability upon request

- One step article tracking system 